\title{
PENERAPAN METODE HYBRID FIS TSUKAMOTO DAN ALGORITMA GENETIKA UNTUK PREDIKSI CURAH HUJAN DI DAERAH BATU
}

\author{
Ida Wahyuni ${ }^{1}$, Fadhli Almu'iini Ahda ${ }^{2}$, Philip Faster Eka Adipraja ${ }^{3}$ \\ ${ }^{1,2,3}$ Program Studi Informatika, STMIK Asia Malang, Jalan Soekarno Hatta-Rembuksari No.1A, \\ Malang, Indonesia, (0341) 478877 \\ Email: ${ }^{1}$ idawahyuni@asia.ac.id, ${ }^{2}$ fadhlial@asia.ac.id, ${ }^{3}$ philipfaster@gmail.com
}

(Naskah masuk: 31 Mei 2018, diterima untuk diterbitkan: 28 Agustus 2018)

\begin{abstract}
Abstrak
Curah hujan yang semakin tidak menentu memberikan efek yang cukup signifikan pada bidang pertanian dan perkebunan. Salah satu bidang perkebunan yang memanfaatkan pola curah hujan adalah perkebunan apel. Petani apel membutuhkan perhitungan curah hujan untuk menentukan kapan proses pembungaan yang tepat agar hasil panen yang dihasilkan dapat maksimal. Namun, karena tidak menentunya pola curah hujan, petani menjadi kesulitan dalam menentukan waktu pembungaan dan panen apel menjadi tidak maksimal. Pada penelitian ini dibuat sebuah pemodelan yang paling optimal dalam memprediksi curah hujan di daerah Batu, Jawa Timur menggunakan metode hybrid FIS Tsukamoto dan algoritma genetika. Metode hybrid yang dilakukan adalah mengoptimasi batasan fungsi keanggotaan FIS Tsukamoto menggunakan algoritma genetika. Setelah proses pengujian, penerapan metode Metode hybrid FIS Tsukamoto dan algoritma genetika dapat digunakan untuk memprediksi curah hujan dengan error RMSE lebih kecil jika dibandingkan dengan FIS Tsukamoto tanpa optimasi. Nilai error RMSE pada daerah Junggo sebesar 6.485, pada daerah Pujon sebesar 6.932, pada daerah Tinjomulyo sebesar 5.969, pada daerah Ngujung sebesar 5.498.
\end{abstract}

Kata kunci: Algoritma Genetika, Curah Hujan, FIS Tsukamoto, Hybrid, Kota Batu, Prediksi

\section{APPLICATION OF HYBRID FIS TSUKAMOTO AND GENETIC ALGORITHM FOR RAINFALL PREDICTION IN BATU REGION}

\begin{abstract}
The erratic rainfall has a significant effect on agriculture and plantations. One area of plantations that utilizes rainfall patterns is apple plantations. Apple farmers need rainfall calculations to determine when the flowering process is right so that the yield can be maximized. However, due to the uncertainty of rainfall patterns, farmers have difficulty in determining the time of flowering and harvesting apples to be not optimal. In this study, the most optimal modeling was used to predict rainfall in the Batu area, East Java using the hybrid FIS Tsukamoto method and genetic algorithm. The hybrid method used is to optimize the boundary function of Tsukamoto's FIS membership using a genetic algorithm. After the testing process, the application of the hybrid method of the Tsukamoto FIS method and the genetic algorithm can be used to predict rainfall with a smaller RMSE error compared to the FIS Tsukamoto without optimization. RMSE error value in Junggo area is 6,485, in Pujon area is 6,932, in Tinjomulyo area is 5,969, in Ngujung area is 5,498.
\end{abstract}

Keywords: Genetic Algorithm, Rainfall, FIS Tsukamoto, Hybrid, Batu City, Prediction

\section{PENDAHULUAN}

Curah hujan yang tidak menentu kini sudah menjadi permasalahan yang cukup krusial di bidang pertanian dan perkebunan (Wahyuni, Mahmudy, \& Iryani, 2016). Bidang tersebut mendapatkan dampak yang cukup signifikan terhadap perubahan pola curah hujan. Salah satu bidang perkebunan yang mendapat dampak buruk dari tidak menentunya curah hujan adalah perkebunan apel. Curah hujan yang tidak menentu membuat petani apel mengalami kesulitan dalam menentukan waktu pembungaan apel. Pembungaan pohon apel yang seharusnya setiap musim kemarau (biasanya dimulai pada awal Bulan Juli) menjadi tidak maksimal (Borchert, 1983). Hal tersebut disebabkan karena pola curah hujan yang tidak menentu bahkan dapat terjadi hujan sepanjang tahun atau musim kering yang lebih lama. Karena tidak menentunya curah hujan yang terjadi, hasil pembungaan apel menjadi kurang maksimal dan baik tidak nya pembuaan pada tanaman apel 
akan berpengaruh pada hasil panen (Tutin \& Fernandez, 1993).

Daerah Batu, Jawa Timur merupakan salah satu daerah dataran tinggi di Jawa Timur dengan luas wilayah mencapai $0,42 \%$ dari total luas Provinsi Jawa Timur atau sekitar 19.908,72 ha (BPS, 2015). Karena lokasinya yang berupa perbukitan dan pegunungan yang dingin, daerah Batu mempunyai potensi yang bagus sebagai pusat budidaya apel di Indonesia (Indahwati, Herdrarto, \& Izzati, 2013). Menurut data BPS Kota Batu, luas perkebunan apel di Daerah Batu mencapai 2.993,89 Ha yang terpusat di Kecamatan Bumiaji yang tersebar di beberapa desa antara lain Desa Sumbergondo, Desa Tulungrejo, Desa Punten, Desa Sumberbrantas, Desa Gunungsari, Desa Bumiaji, Desa Giripurno, dan Desa Bulukerto.

Curah hujan pada Daerah Batu, Jawa Timur juga menjadi tidak menentu setelah terjadi perubahan iklim (BPS, 2015). Karena tidak menentunya curah hujan yang terjadi belakangan ini, produksi apel pada tahun 2014 menurun sebanyak $15 \%$ menjadi 708,438. Hasil tersebut jauh lebih sedikit jika dibandingkan dengan hasil panen apel pada tahun 2013 yaitu sebesar 838,915 ton (BPS, 2015). Penurunan panen apel tersebut disebabkan karena pada tahun 2014 di Bulan September sampai Oktober menjadi bulan kering karena tidak terjadi hujan. Jumlah hari hujan paling sedikit dialami pada bulan Agustus 2014 dan jumlah hari hujan paling banyak dialami pada bulan Desember 2014 dan Januari 2015. Curah hujan tertinggi mencapai 412 mm terjadi pada bulan Desember 2014. Fenomena tersebut menyebabkan kondisi cuaca tahun 2014 tidak menentu dan sulit diprediksi (BPS, 2015).

Ada banyak metode yang dapat digunakan nntuk prediksi, salah satunya adalah metode fuzzy inference system (FIS) Tsukamoto. FIS Tsukamoto pernah digunakan oleh Wahyuni, Mahmudy, \& Iryani (2016) untuk prediksi curah hujan di daerah Tengger, Jawa Timur pada empat kecamatan. Hasil Error RMSE terkecil berada di Kecamatan Tutur yaitu 8.64. Hasil error tersebut masih lebih besar jika dibandingkan dengan metode FIS Tsukamoto yang sudah optimasi dengan algoritma genetika (Wahyuni \& Mahmudy, 2017). Proses optimasi yang dilakukan adalah optimasi pada batasan fungsi keanggotaan FIS Tsukamoto, sehingga dapat ditemukan batasan fungsi keanggotaan yang paling maksimum dari pemodelan FIS Tsukamoto untuk peramalan curah hujan di daerah Tengger. Optimasi memberikan nilai error yang lebih kecil yaitu nilai RMSE di daerah Tutur menjadi 6.63.

Pada penelitian ini, akan digunakan metode hybrid FIS Tsukamoto dan algoritma genetika (Hybrid FIS-GA) untuk memprediksi curah hujan di daerah Batu. Data yang digunakan untuk memprediksi curah hujan adalah data historis curah hujan selama 10 tahun kebelakang mulai tahun 2005 sampai tahun 2014. Variabel yang akan dijadikan parameter input mengacu pada pemodelan yang digunakan oleh Wahyuni \& Mahmudy (2017) yang telah berhasil digunakan untuk memprediksi curah hujan pada daerah Tengger. Algoritma genetika akan digunakan sebagai metode yang akan mengoptimasi batasan fungsi keanggotaan pada FIS Tsukamoto untuk mendapatkan error RMSE terkecil.

\section{PREDIKSI CURAH HUJAN DENGAN FIS TSUKAMOTO DI DAERAH BATU}

FIS Tsukamoto pernah digunakan untuk memprediksi curah hujan di Daerah Batu Jawa Timur oleh Wahyuni \& Ahda (2018). Pada penelitian tersebut digunakan empat kriteria input yaitu Zt-1 (curah hujan rata-rata selama 10 hari kebelakang), Zt-2 (curah hujan rata-rata selama 20 hari kebelakang), Zt-17 (curah hujan rata-rata selama 170 hari kebelakang), Zt-34 (curah hujan rata-rata selama 340 hari kebelakang). Model untuk jumlah output ada satu output yaitu Zt atau curah hujan rata-rata selama 10 hari kedepan. Data yang digunakan adalah data historis curah hujan pada Daerah Batu selama 10 tahun dimulai dari tahun 2005 sampai 2014. Lokasi pengambilan data dilakukan pada empat pos hujan di Daerah Batu yaitu Pos Hujan Junggo, Pujon, Tinjomulyo, dan Ngujung. Pemodelan FIS Tsukamoto pada penelitian tersebut memberikan hasil prediksi curah hujan dengan nilai Root Mean Square Error (RMSE) paling besar pada daerah Pos Hujan Pujon yaitu 9.407. Hasil RMSE pada keempat lokasi pos hujan di Daerah Batu ditunjukkan pada Tabel 1.

\begin{tabular}{ccc}
\multicolumn{3}{c}{ Tabel 1. Nilai RMSE pada Empat Lokasi Pos Hujan di Daerah } \\
Batu \\
\hline No. & Lokasi Pos Hujan & RMSE FIS Tsukamoto \\
\hline 1 & Junggo & 9.196 \\
2 & Pujon & 9.407 \\
3 & Tinjomulyo & 8.798 \\
4 & Ngujung & 8.825 \\
\hline
\end{tabular}

Nilai RMSE yang dihasilkan oleh FIS Tsukamoto masih dapat diperkecil lagi dengan beberapa optimasi. Salah satu optimasi yang dapat digunakan adalah optimasi derajat keanggotaan (Kurnianingtyas, Mahmudy, \& Widodo, 2017) atau optimasi batasan fungsi keanggotaan pada FIS Tsukamoto dengan algoritma genetika (Wahyuni \& Mahmudy, 2017). Algoritma genetika dapat digunakan untuk mengoptimasi batasan-batasan keanggotaan himpunan fuzzy agar nilai RMSE yang dihasilkan semakin kecil.

\section{HIBRID FIS TSUKAMOTO DAN ALGORITMA GENETIKA}

Pada penggunaan FIS Tsukamoto untuk proses prediksi dibutuhkan penentuan batasan-batasan fungsi keanggotaan himpunan fuzzy yang sesuai agar didapatkan hasil prediksi yang akurat. Batas-batas tersebut bisa ditentukan secara otomatis dengan 
menggunakan algoritma genetika. Algoritma genetika dalam penerapannya memiliki beberapa tahap untuk menyelesaikan masalah, yaitu representasi kromosom, inisialiasi populasi, menghitung nilai fitness, proses reproduksi yaitu pindah silang dan mutasi, serta proses seleksi (Hannawati, Thiang, \& Eleazar, 2002).

\subsection{Representasi Kromosom}

Representasi kromosom dirancang untuk menemukan optimasi solusi dari permsalahan yang ada. Pada penelitian ini, kromosom dibentuk dengan Real Coded Genetic Algorithms (RCGA). RCGA menggunakan sebuah array yang berisikan bilangan real sebagai representasi kromosom untuk batasan fungsi keanggotaan (Armanda \& Mahmudy, 2016).

Dalam satu kromosom ada delapan gen. Setiap gen yang ada pada satu kromosom mewakili batasan fungsi keanggotaan setiap kriteria input pada pemodelan dengan FIS Tsukamoto. Gen pertama dan kedua digunakan untuk mewakili solusi batasan fungsi keanggotaan kriteria pertama, gen ketiga dan keempat digunakan untuk mewakili solusi batasan fungsi keanggotaan kriteria kedua, gen kelima dan keenam digunakan untuk mewakili solusi batasan fungsi keanggotaan kriteria ketiga, serta gen ketujuh dan kedelapan digunakan untuk mewakili solusi batasan fungsi keanggotaan kriteria keempat. Nilai dari masing-masing gen akan dibangkitkan secara acak dari range $[0,38]$. Nilai range tersebut diambil dari nilai batasan batasan fungsi keanggotaan fuzzy pada penelitian sebelumnya (Wahyuni \& Ahda, 2018). Ilustrasi representasi kromosom ditunjukkan pada Gambar 1 berikut ini.

K1 \begin{tabular}{|c|c|c|c|c|c|c|c|c|c|c|}
\hline a1 & a2 & a3 & a4 & a5 & a6 & a7 & a8 & a9 & a10 & a11 \\
\hline
\end{tabular}
Zt-1
Gambar 1. Ilustrasi Representasi Kromosom

Keterangan:

$K i=$ Kromosom ke-i

$a 1, a 2=$ Segmen batasan fungsi keanggotaan Zt-1

$a 3, a 4=$ Segmen batasan fungsi keanggotaan $\mathrm{Zt}-2$

$a 5, a 6=$ Segmen batasan fungsi keanggotaan $\mathrm{Zt}-17$

$a 7, a 8=$ Segmen batasan fungsi keanggotaan $\mathrm{Zt}-34$

$a 9, a 10, a 11=$ Segmen batasan fungsi keanggotaan $\mathrm{Zt}$

Contoh representasi kromosom dengan menggunakan pengkodean real ditunjukkan pada Gambar 2.

\section{\begin{tabular}{|l|l|l|l|l|l|l|l|l|l|l|l|}
\hline $\mathrm{K} 1$ & 33.1 & 12.5 & 1.8 & 7.8 & 35.1 & 25.2 & 9.4 & 14.3 & 1.3 & 7.4 & 14.3 \\
\hline
\end{tabular} Gambar 2. Contoh Representasi Kromosom}

Pada saat proses representasi kromosom, perlu dilakukan pengurutan nilai gen pada kromosom secara ascending. Nilai gen diurutkan sesuai dengan segmen yang dimodelkan pada representasi kromosom. Hasil pengurutan kromosom dapat dilihat pada Gambar 3.

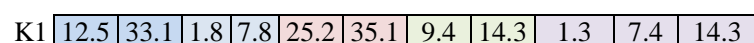
Gambar 3. Contoh Representasi Kromosom Setelah Diurutkan

\subsection{Inisialisasi Populasi}

Pada tahapan inisialisasi populasi ditentukan jumlah populasi dalam algoritma genetika (popSize). Sebagai contoh, popSize dibuat 3 kromosom atau bisa dikatakan jumlah populasi adalah 3 mulai dari $K_{1} \ldots K_{n}$, dimana $n=3$. Contoh inisialisasi populasi ditunjukkan pada Tabel 2.

Tabel 2. Ilustrasi Inisialisasi Populasi

\begin{tabular}{llllllllllll}
\multicolumn{10}{c}{ Tabel 2. Ilustrasi Inisialisasi Populasi } \\
\hline K & G1 & G2 & G3 & G4 & G5 & G6 & G7 & G8 & G9 & G10 & G11 \\
\hline K1 & 12.5 & 33.1 & 1.8 & 7.8 & 25.2 & 35.1 & 9.4 & 14.3 & 1.3 & 7.4 & 14.3 \\
K2 & 16.2 & 31.2 & 3.2 & 9.2 & 16.5 & 23.1 & 3.4 & 18.6 & 9.7 & 27.1 & 34.4 \\
K3 & 5.2 & 21.9 & 11.1 & 36.7 & 10.0 & 17.1 & 6.2 & 27.4 & 6.8 & 16.0 & 18.2 \\
\hline
\end{tabular}

\subsection{Perhitungan Nilai Kebugaran (Fitness)}

Fungsi kebugaran digunakan untuk mengukur nilai kebaikan dari solusi yang didapatkan dari perhitungan algoritme genetika (Mahmudy, Marian, \& Luong, 2013). Proses penghitungan nilai kebugaran pada penelitian ini dilakukan dengan menerapkan menerapkan FIS Tsukamoto untuk mengetahui kromosom yang menghasilkan error RMSE paling kecil. Solusi yang dicari dalam penelitian ini adalah optimasi batasan fungsi keanggotaan FIS Tsukamoto adalah error RMSE dari hasil prediksi curah hujan yang paling kecil. Apabila semakin kecil nilai error RMSE yang dimiliki oleh kromosom, maka semakin baik kromosom tersebut, sehingga perhitungan nilai kebugaran $(f)$ dinyatakan dalam Persamaan 1 .

$$
f=\frac{1}{e}
$$

Keterangan:

$f=$ nilai kebugaran (fitness)

$e=$ error $\mathrm{RMSE}$

Nilai error RMSE dihitung dengan mencari nilai galat yaitu selisih antara data aktual dengan data hasil prediksi. Untuk mengetahui nilai galat dan nilai error digunakan rumus galat dan rumus RMSE yang dinyatakan dalam Persamaan 2 dan Persamaan 3.

$$
\text { Galat }=y-y^{\prime}
$$

Keterangan:

$y=$ data aktual

$y^{\prime}=$ data hasil prediksi

$$
R M S E=\sqrt{\frac{1}{n} \sum_{i=1}^{n}\left(y_{i}-y_{i}^{\prime}\right)^{2}}
$$

Keterangan:

RMSE = Root Mean Squared Error

$n=$ jumlah data

$y=$ data aktual 
$y^{\prime}=$ data hasil prediksi

Proses penghitungan FIS Tsukamoto untuk prediksi curah hujan di Daerah Batu dijelaskan pada penelitian sebelumnya (Wahyuni \& Ahda, 2018), sedangkan ilustrasi penghitungan nilai kebugaran pada kromosom K1 sampai K3 ditunjukkan pada Tabel 3.

\begin{tabular}{ccccc}
\multicolumn{6}{c}{ Tabel 3. Ilustrasi Penghitungan Nilai Kebugaran pada Kromosom } \\
\hline K & Daerah & RMSE & $\overline{\boldsymbol{x}}$ RMSE & $\boldsymbol{f}$ \\
\hline \multirow{4}{*}{ K1 } & Junggo & 7.85 & & \\
& Pujon & 6.07 & 7.128 & 0.14029 \\
& Tinjomulyo & 7.91 & & \\
& Tutur & 6.68 & & \\
K2 & Junggo & 9.871 & & \\
& Pujon & 7.875 & 9.471 & 0.10559 \\
& Tinjomulyo & 8.420 & & \\
& Tutur & 9.471 & & \\
K3 & Junggo & 8.361 & & \\
& Pujon & 7.453 & 7.006 & 0.14273 \\
& Tinjomulyo & 7.033 & & \\
\hline
\end{tabular}

\subsection{Seleksi}

Proses yang paling penting dalam algoritma genetika adalah proses reproduksi, sehingga untuk memilih parent yang akan dioptimasi butuh metode khusus. Oleh karena itu dibutuhkan proses seleksi untuk memilih parent yang akan direproduksi. Metode seleksi yang akan digunakan adalah seleksi Roulette wheel, dimana metode seleksi ini akan memilih parent untuk lolos ke proses reproduksi dengan memperhitungkan nilai probabilitas dari setiap parent (Herrera, Lozano, \& Verdegay, 1998). Langkah awal untuk memulai seleksi Roulette wheel adalah menghitung nilai probabilitas dan kumulatif probabilias dari masing-masing kromosom. Contoh pehitungan nilai probabilitas dan kumulatif probabilias pada kromosom K1 sampai K3 ditunjukkan pada Tabel 4.

Tabel 4. Hasil Penghitungan Probabilitas Setiap Individu

\begin{tabular}{cccc}
\hline Kromosom & $\begin{array}{c}\text { Nilai } \\
\text { Kebugaran }(\boldsymbol{f})\end{array}$ & Probabilitas & Kumulatif \\
\hline K1 & 0.14029 & 0.351648352 & 0.351648352 \\
K2 & 0.10559 & 0.263736264 & 0.615384615 \\
K3 & 0.14273 & 0.384615385 & 1 \\
\hline
\end{tabular}

Setelah nilai probabilitas dan kumulatif probabilitas diketahui, akan dilakukan pengacakan nilai random $(\mathrm{R})$ antara $[0,1]$ sebanyak dua kali untuk menentukan kromosom yang akan dijadikan parent dengan ketentuan $\mathrm{K}[\mathrm{n}-1]<\mathrm{R}<\mathrm{K}[\mathrm{n}]$. Hasil seleksi Roulette wheel lebih detail ditunjukkan pada Tabel 5.

\begin{tabular}{cc}
\multicolumn{2}{c}{ Tabel 5. Kromosom Terpilih dari Seleksi Roulette Whell } \\
\hline Nilai Random (R) & Kromosom Terpilih \\
\hline 0.07720 & K1 \\
0.25347 & K2 \\
\hline
\end{tabular}

\subsection{Pindah Silang}

Dalam penelitian ini metode pindah silang yang digunakan adalah extended intermediate crossover (Muhlenbein \& Schlierkamp-Voosen, 1993). Sebelum melakukan pindah silang, ditentukan terlebih dahulu variabel crossover rate (cr) yaitu salah satu parameter dalam algoritma genetika untuk menentukan jumlah offspring hasil pindah silang (Herman, Yusuf, \& Mariyam, 2009). Jumlah offspring didapat dari rumus offspring $=\operatorname{cr} \mathrm{x}$ popSize. Nilai crossover rate ditentukan dengan rentang nilai $[0,1]$. Sebagai contoh nilai cr yang akan digunakan adalah 0.5, sehingga jumlah offspring $=0.5 \times 3=1,5=2$.

Proses pindah silang dengan extended intermediate crossover dimulai dengan memilih parent $(p)$. Parent yang akan digunakan dalam proses pindah silang ini adalah dua buah kromosom yang sudah dipilih dengan metode seleksi Roulette wheel pada tahap sebelumnya. Offspring $(O)$ diproduksi dengan sebuah rumus yang dituliskan pada Persamaan 3. Untuk melihat lebih detail langkah-langkah proses extended intermediate crossover dapat dilihat pada Gambar 4.

$$
O_{i}=p_{i}^{2}+\alpha_{1}\left(p_{i}{ }^{2}-p_{i}{ }^{1}\right)
$$

Keterangan:

$\alpha=$ nilai random antara interval $[-0.25,1.25]$

$O=$ offspring

$p=$ parent

\begin{tabular}{l|l|l|l|l|l|l|l|l|l|l|l|} 
C1 & 12.5 & 33.1 & 1.8 & 7.8 & 25.2 & 35.1 & 9.4 & 14.3 & 1.3 & 7.4 & 14.3 \\
\hline
\end{tabular}

\begin{tabular}{ll|l|l|l|l|l|l|l|l|l|l|l|} 
C2 2 & 16.2 & 31.2 & 3.2 & 9.2 & 16.5 & 23.1 & 3.4 & 18.6 & 9.7 & 27.1 & 34.4 \\
\hline
\end{tabular}

\begin{tabular}{l|l|l|l|l|l|l|l|l|l|l|l|}
$\boldsymbol{\alpha} \alpha$ & 0.1 & 0.48 & -0.6 & 0.8 & 0.57 & 0.4 & 0.2 & -0.1 & 0.9 & 0.2 & -0.2 \\
\cline { 2 - 8 } & 0.1 & 0.1 & &
\end{tabular}

\begin{tabular}{lllllll|l|l|l|l|l|l|l|}
01 & 16.5 & 30.2 & 2.3 & 10.3 & 11.5 & 18.3 & 2.2 & 18.1 & 17.2 & 31.0 & 30.3 \\
\hline
\end{tabular}

Gambar 4. Contoh Proses Extended Intermediate Crossover

\subsection{Mutasi}

Metode mutasi yang digunakan pada penelitian ini adalah simple random mutation. Sebelum melakukan pindah silang, ditentukan terlebih dahulu variabel mutation rate $(\mathrm{mr})$ yaitu salah satu parameter dalam algoritma genetika untuk menentukan jumlah offspring hasil mutasi (Herman et al., 2009). Misalkan variabel $m r$ yang akan digunakan adalah 0.1 , dimana nilai $m r$ ini telah ditentukan sebelumnya dari rentang nilai $[0,1]$. Proses mutasi akan menghasilkan offspring dengan rumus offspring $=m r \times$ popSize $=0.1 \times 3=0.3=1$.

Proses mutasi ini dimulai dengan menentukan offspring $(O)$ dari parent $(p)$ dengan menggunakan rumus dari Persamaan 4 (Michalewicz, 1992). Untuk melihat lebih detail proses simple random mutation dapat dilihat pada Gambar 5.

$$
O_{i}=p_{i}(1+\alpha)
$$

Keterangan:

$\alpha=$ nilai random antara interval $[-0.1,0.1]$ 
$O=$ offspring

$p=$ parent

\begin{tabular}{ll|l|l|l|l|l|l|l|l|l|l|}
$\mathbf{C} 1$ & 12.5 & 33.1 & 1.8 & 7.8 & 25.2 & 35.1 & 9.4 & 14.3 & 1.3 & 7.4 & 14.3 \\
\hline
\end{tabular}

\begin{tabular}{llllllll|l|l|l|l|l|l|}
$\alpha$ & -0.03 & 0.02 & 0.03 & 0.04 & 0.05 & 0.04 & -0.10 & 0.01 & 0.04 & 0.09 & 0.10 \\
\hline
\end{tabular}

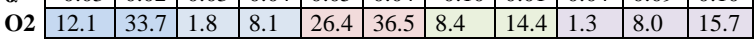

Gambar 5. Contoh Proses Simple Random Mutation

\subsection{Elitisme (Elitism)}

Setelah proses pindah silang dan mutasi selesai, kromosom parent dan offspring hasil pindah silang dan mutasi akan dihitung nilai kebugarannya sesuai dengan Persamaan 1. Hasil perhitungan nilai kebugaran setelah proses pindah silang dan mutasi ditunjukkan pada Tabel 6.

Tabel 6. Hasil Penghitungan Nilai KebugaranSetelah Proses Reproduksi

\begin{tabular}{cc}
\hline Kromosom & Nilai Kebugaran \\
\hline K1 & 0.14029 \\
K2 & 0.10559 \\
K3 & 0.14273 \\
O1 & 0.1599 \\
O2 & 0.1398 \\
\hline
\end{tabular}

Langkah selanjutnya akan dipilih tiga kromosom (sesuai dengan jumlah popSize) dengan nilai kebugaran terbaik untuk lolos ke generasi selanjutnya. Metode seleksi yang akan digunakan adalah elitisme (elitism) yaitu pemilihan kromosom dengan memilih nilai kebugaran (fitness) yang paling besar sesuai dengan jumlah popSize (Wu, Long, \& Liu, 2015). Contoh hasil seleksi dengan elitisme dapat dilihat pada Tabel 7.

\begin{tabular}{cc}
\multicolumn{2}{c}{ Tabel 7. Hasil Seleksi Elitsm } \\
\hline Kromosom & Nilai Kebugaran \\
\hline K2 & 0.10559 \\
O2 & 0.1398 \\
K1 & 0.14029 \\
\hline
\end{tabular}

\subsection{Kondisi Berhenti}

Pada penelitian ini, proses algoritme genetika akan berhenti jika jumlah generasi maksimal (Jafarian, 2010). Jumlah generasi akan ditentukan pada tahap pengujian algortima genetika untuk mencari jumlah generasi yang paling optimal. Jumlah generasi tersebut akan di uji pada rentang 100 sampai 500 generasi.

\section{HASIL DAN PEMBAHASAN}

Pada penelitian ini akan dilakukan prediksi curah hujan pada Daerah Batu dengan data historis yang didapat dari empat lokasi pos hujan, yaitu Pos Hujan yaitu Pos Hujan Junggo, Pujon, Tinjomulyo, dan Ngujung. Ada 360 data curah hujan yang didapatkan dari tahun 2005-2014 dan akan menjadi acuan prediksi. Setiap data mewakili rata-rata curah hujan selama sepuluh hari, sehingga hasil prediksi juga akan menghasilkan data curah hujan pada sepuluh hari kedepan atau dalam bentuk dasarian. Kriteria input FIS Tsukamoto yang digunakan pada penelitian ini sama dengan yang digunakan pada penelitian sebelumnya (Wahyuni \& Ahda, 2018).

Sebelum memperoleh parameter algoritma genetika yang paling optimal untuk optimasi FIS Tsukamoto, dilakukan proses pengujian pada parameter-parameter algoritma genetika. Pengujian tersebut meliputi pengujian jumlah populasi (popSize), kombinasi nilai $c r$ dan $m r$, dan jumlah generasi.

\subsection{Pengujian Jumlah Populasi}

Proses pengujian jumlah populasi dilakukan sebanyak lima kali terhadap jumlah populasi 50 sampai 250 dengan kenaikan jumlah populasi sebanyak 50. Nilai cr dan $\mathrm{mr}$ awal yang akan dipakai yaitu 0.9 dan 0.1 sedangkan jumlah generasi awal yang dipakai adalah 100. Nilai fitness yang dihasilkan dari lima kali pengujian akan dihitung rata-ratanya. Dari hasil rata-rata tersebut akan diketahui jumlah populasi yang paling optimum. Hasil pengujian jumlah populasi dapat dilihat lebih jelas pada Tabel 8.

\begin{tabular}{|c|c|c|c|c|c|c|}
\hline \multirow{3}{*}{$\begin{array}{l}\text { Jumlah } \\
\text { Populasi }\end{array}$} & \multicolumn{5}{|c|}{ Nilai Kebugaran } & \multirow{3}{*}{$\begin{array}{c}\bar{x} \text { Nilai } \\
\text { Kebugaran }\end{array}$} \\
\hline & \multicolumn{5}{|c|}{ Percobaan Ke- } & \\
\hline & 1 & 2 & 3 & 4 & 5 & \\
\hline 50 & 0.104 & 0.138 & 0.080 & 0.079 & 0.154 & 0.111 \\
\hline 100 & 0.120 & 0.091 & 0.096 & 0.148 & 0.131 & 0.117 \\
\hline 150 & 0.139 & 0.139 & 0.138 & 0.149 & 0.087 & 0.131 \\
\hline 200 & 0.112 & 0.111 & 0.099 & 0.124 & 0.150 & 0.119 \\
\hline 250 & 0.146 & 0.148 & 0.132 & 0.160 & 0.100 & 0.137 \\
\hline
\end{tabular}

Berdasarkan Tabel 8 ditunjukkan bahwa ratarata nilai kebugaran terbaik didapatkan pada jumlah populasi 250. Pada jumlah populasi tersebut didapatkan nilai kebugaran tertinggi yaitu 0.137. Jumlah populasi tersebut juga masih dalam batas yang normal dan tidak membutuhkan waktu komputasi yang lama (Mahmudy, Marian, \& Luong, 2012). Grafik perubahan nilai nilai kebugaran sesuai dengan jumlah populasi dapat dilihat lebih jelas pada Gambar 6.

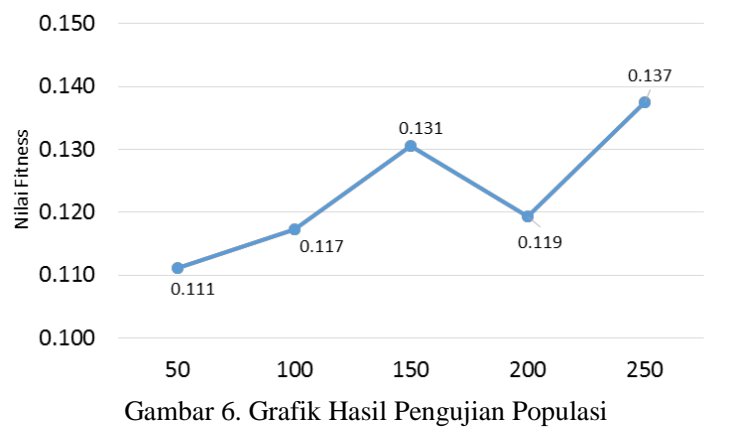

\subsection{Pengujian Kombinasi Nilai $\mathrm{cr}$ dan $\mathrm{mr}$}

Proses pengujian kombinasi nilai $\mathrm{cr}$ dan $m r$ didasarkan pada teori Grefenstette (Grefenstette, 
1986) untuk menentukan nilai $c r$ nya. Jumlah populasi dan jumlah generasi terbaik akan digunakan dalam pengujian $\mathrm{cr}$ dan $m r$. Pengujian akan dilakukan sebanyak lima kali dan nilai kebugaran yang dihasilkan dari lima kali pengujian akan dihitung rata-ratanya. Dari hasil rata-rata tersebut akan diketahui jumlah $c r$ dan $m r$ yang paling optimum. Hasil pengujian pada jumlah populasi ditunjukkan pada Tabel 9.

Tabel 9. Hasil Pengujian Kombinasi $c r$ dan $m r$

\begin{tabular}{|c|c|c|c|c|c|c|}
\hline \multirow{3}{*}{$\begin{array}{c}\text { Jumlah } \\
\qquad r\end{array}$} & \multicolumn{5}{|c|}{ Nilai Kebugaran } & \multirow{3}{*}{$\begin{array}{c}\bar{x} \text { Nilai } \\
\text { Kebugaran }\end{array}$} \\
\hline & \multicolumn{5}{|c|}{ Percobaan Ke- } & \\
\hline & 1 & 2 & 3 & 4 & 5 & \\
\hline 0.45 & 0.156 & 0.070 & 0.115 & 0.068 & 0.131 & 0.108 \\
\hline 0.6 & 0.137 & 0.094 & 0.113 & 0.101 & 0.072 & 0.103 \\
\hline 0.95 & 0.117 & 0.094 & 0.157 & 0.103 & 0.137 & 0.122 \\
\hline
\end{tabular}

Berdasarkan Tabel 9 ditunjukkan bahwa ratarata nilai kebugaran yang paling baik didapatkan pada kombinasi nilai cr 0.95 dan nilai $m r$ 0.05. Pada kombinasi nilai $\mathrm{cr}$ dan $m r$ tersebut didapatkan nilai kebugaran tertinggi yaitu 0.122 . Ketika nilai $c r$ semakin kecil maka hasil nilai kebugaran (fitness) tidak akan optimal karena algoritma genetika menggunakan metode random search yang tidak akan mampu mengeksplorasi pencarian solusi secara efektif saat nilai $\mathrm{cr}$ kecil (Wahyuni \& Mahmudy, 2017). Grafik perubahan nilai kebugaran sesuai dengan nilai $c r$ dan $m r$ dapat dilihat pada Gambar 7 .

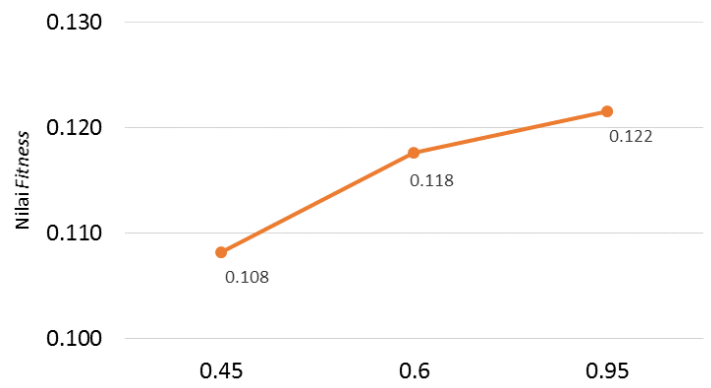

Gambar 7. Grafik Hasil Pengujian Kombinasi $c r$ dan $m r$

\subsection{Pengujian Jumlah Generasi}

Pengujian jumlah generasi dilakukan sebanyak lima kali terhadap jumlah generasi 100 sampai 500 dengan kenaikan jumlah generasi sebanyak 100 . Nilai $\mathrm{cr}$ dan $m r$ yang akan digunakan yaitu 0.95 dan 0.05 , sedangkan jumlah populasi yang digunakan adalah 250 sesuai dengan hasil pengujian sebelumnya. Nilai kebugaran yang dihasilkan dari lima kali pengujian akan dihitung rata-ratanya. Dari hasil rata-rata tersebut akan diketahui jumlah generasi yang paling optimum. Hasil pengujian pada jumlah generasi dapat dilihat lebih jelas pada Tabel 10.
Tabel 10. Hasil Pengujian Jumlah Generasi

\begin{tabular}{cccccccc}
$\begin{array}{c}\text { Jumlah } \\
\text { Generasi }\end{array}$ & \multicolumn{6}{c}{$\begin{array}{c}\text { Nilai Kebugaran } \\
\text { Percobaan Generasi Ke- }\end{array}$} & $\begin{array}{c}\overline{\boldsymbol{x}} \text { Nilai } \\
\text { Kebugaran }\end{array}$ \\
$\mathbf{1 0 0}$ & 0.117 & 0.094 & 0.157 & 0.103 & 0.137 & 0.122 \\
$\mathbf{2 0 0}$ & 0.123 & 0.132 & 0.085 & 0.095 & 0.087 & 0.105 \\
$\mathbf{3 0 0}$ & 0.105 & 0.098 & 0.116 & 0.134 & 0.151 & 0.121 \\
$\mathbf{4 0 0}$ & 0.088 & 0.136 & 0.132 & 0.146 & 0.104 & 0.121 \\
$\mathbf{5 0 0}$ & 0.130 & 0.127 & 0.151 & 0.105 & 0.105 & 0.123
\end{tabular}

Berdasarkan Tabel 10 dapat dilihat bahwa ratarata nilai kebugaran terbaik didapatkan pada jumlah generasi 100. Pada jumlah generasi tersebut didapatkan nilai fitness 0.123 dan tidak mengalami peningkatan yang signifikan bahkan mengalami penurunan nilai kebugaran pada jumlah generasi yang lebih besar. Hal tersebut juga pernah dialami pada penelitian sebelumnya yang menyatakan bahwa kenaikan nilai kebugaran yang diperoleh tidak terlalu signifikan pada jumlah generasi yang lebih besar dari 100 (Mahmudy et al., 2012). Grafik perubahan nilai kebugaran sesuai dengan jumlah generasi dapat dilihat pada Gambar 8.

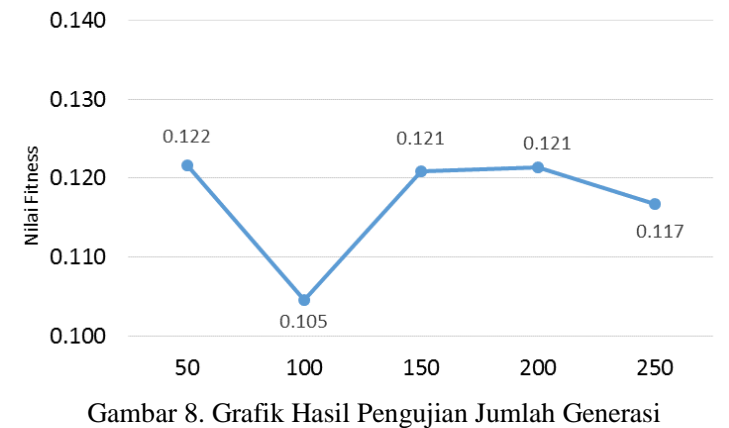

\subsection{Hasil Optimasi Batasan Fungsi Keanggotaan}

Solusi yang dihasilkan dari perhitungan algoritma genetika adalah sebuah kromosom yang memliliki nilai fitness terbaik yang akan dijadikan batasan fungsi keanggotaan pada Tsukamoto FIS. Hasil dari proses pengujian parameter algoritma genetika yang sudah dilakukan mendapatkan nilai parameter yang paling optimal untuk prediksi curah hujan. Parameter tersebut antara lain jumlah populasi 250, kombinasi nilai $c r$ dan $m r$ terbaik yaitu 0.95 dan 0.05, dan jumlah generasi 100. Batasan fungsi keanggotaan yang sudah dioptimasi ditunjukkan pada Gambar 9 sampai Gambar 13. 


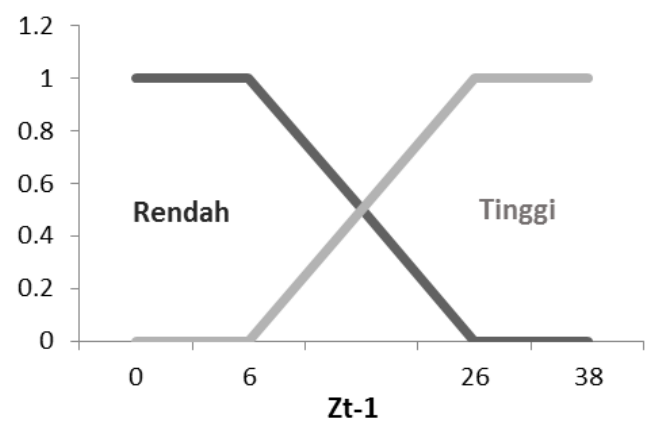

Gambar 9. Hasil Optimasi Batasan Fungsi Keanggotaan Zt-1

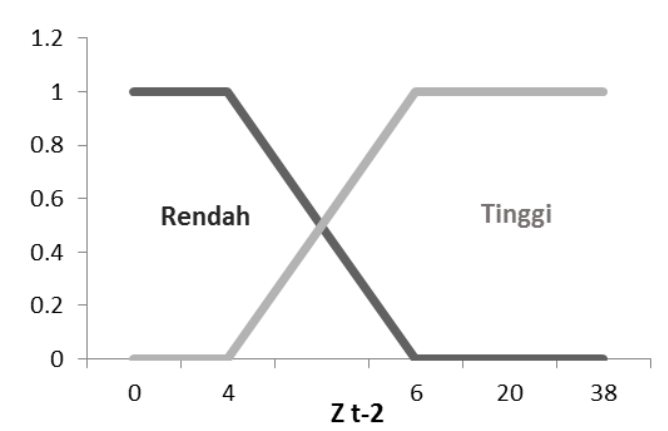

Gambar 10. Hasil Optimasi Batasan Fungsi Keanggotaan Zt-2

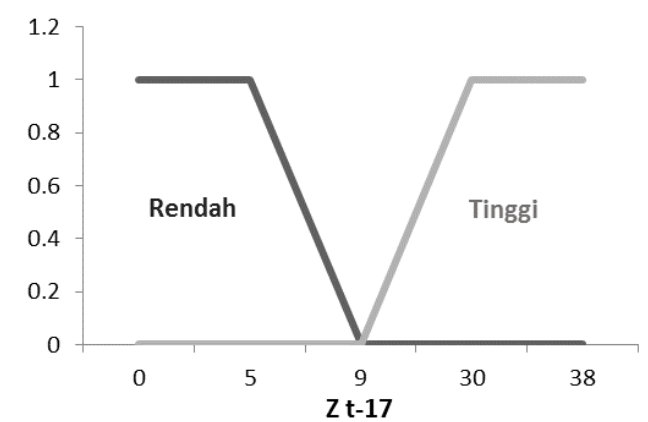

Gambar 11. Hasil Optimasi Batasan Fungsi Keanggotaan Zt-17

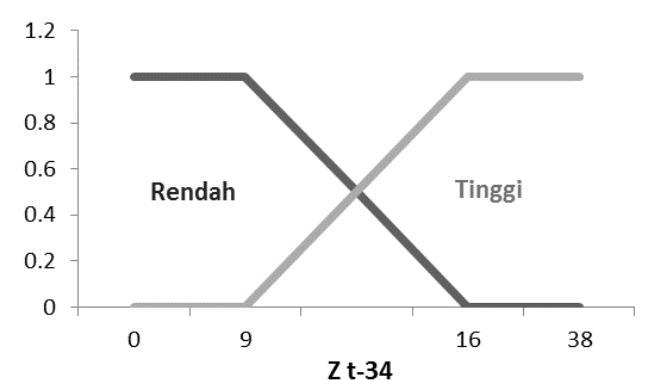

Gambar 12. Hasil Optimasi Batasan Fungsi Keanggotaan Zt-34

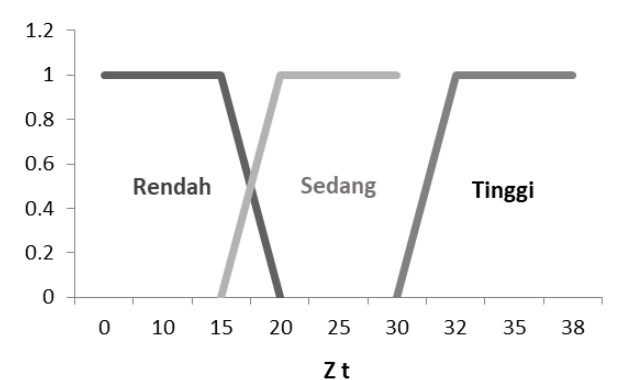

Gambar 13. Hasil Optimasi Batasan Fungsi Keanggotaan Zt

\subsection{Penghitungan Akurasi Hasil Prediksi}

Prediksi curah hujan di Daerah Batu dilakukan di empat lokasi yaitu Junggo, Pujon, Tinjomulyo, dan Ngujung. Hasil dari prediksi curah hujan yang ditunjukkan pada Tabel 11 adalah hasil pada Daerah Junggo. Pada Tabel 11 ditampilkan juga hasil penghitungan galat menggunakan Persamaan 2 . Nilai galat yang dihasilkan akan digunakan untuk menghitung nilai RMSE menggunakan Persamaan 3.

Tabel 11. Hasil Prediksi Curah Hujan pada Daerah Junggo

\begin{tabular}{cccc}
\hline No. & Data Aktual (y) & Hasil Prediksi $\left(\mathbf{y}^{\prime}\right)$ & Galat \\
\hline 1 & 2.400 & 0 & 2.4 \\
2 & 5.300 & 0 & 5.3 \\
3 & 5.364 & 0 & 5.3636363 \\
4 & 0.000 & 3.185 & -3.185 \\
5 & 18.400 & 3.036264 & 15.363736 \\
6 & 13.000 & 10.7911275 & 2.2088724 \\
7 & 13.000 & 12.65690859 & 0.3430914 \\
8 & 6.200 & 12.65690859 & -6.456908 \\
9 & 6.909 & 15.06377898 & -8.154688 \\
10 & 7.400 & 14.80984101 & -7.409841 \\
$\ldots$ & $\ldots$ & $\ldots$ & $\ldots$ \\
350 & 0.000 & 0 & 0 \\
351 & 0.000 & 0 & 0 \\
352 & 0.000 & 0 & 0 \\
353 & 0.000 & 0 & 0 \\
354 & 0.182 & 0 & 0.1818181 \\
355 & 0.000 & 0 & 0 \\
356 & 7.600 & 3.203801653 & 4.3961983 \\
357 & 16.200 & 14.56301897 & 1.6369810 \\
358 & 21.200 & 11.54639226 & 9.6536077 \\
359 & 11.800 & 9.839562698 & 1.9604373 \\
\hline & & &
\end{tabular}

Pada tabel 11 ditunjukkan bahwa hybrid Tsukamoto FIS dan algoritma genetika dapat memprediksi curah hujan di Daerah Junggo, Batu dengan cukup baik. Dapat dilihat bahwa pemodelan metode tersebut dapat memprediksi curah hujan $=0$ dengan tepat di beberapa data. Metode sebelumnya yang menggunakan FIS Tsukamoto tidak dapat melakukan hal tersebut (Wahyuni \& Ahda, 2018).

\subsection{Perbandingan RMSE Hasil Prediksi}

Nilai error RMSE hasil prediksi curah hujan menggunakan hybrid Tsukamoto FIS dan algoritma genetika akan dibandingkan dengan nilai error RMSE hasil prediksi pada penelitian sebelumnya yang dilakukan oleh Wahyuni \& Ahda (2018). Perbandingan dilakukan pada empat lokasi yang sama. Hasil error RMSE dari Tsukamoto FIS dan hybrid hybrid Tsukamoto FIS dan algoritma genetika lebih jelas ditunjukkan pada Table 12 .

\begin{tabular}{ccccc}
\multicolumn{4}{c}{$\begin{array}{c}\text { Tabel 12. Perbandingan Hasil Prediksi antara Metode FIS } \\
\text { Tsukamoto dan Hybrid FIS Tsukamoto dan GA }\end{array}$} \\
\hline No. & Lokasi & $\begin{array}{c}\text { RMSE FIS } \\
\text { Tsukamoto }\end{array}$ & $\begin{array}{c}\text { RMSE Hybrid } \\
\text { FIS Tsukamoto } \\
\text { GA }\end{array}$ & $\begin{array}{c}\text { Kenaikan } \\
\text { Akurasi }\end{array}$ \\
\hline 1 & Junggo & 9.196 & 6.485 & $29.5 \%$ \\
2 & Pujon & 9.407 & 6.932 & $26.3 \%$ \\
3 & Tinjomulyo & 8.798 & 5.969 & $32.2 \%$ \\
4 Ngujung & 8.825 & $\mathbf{5 . 4 9 8}$ & $37.7 \%$ \\
Rata-Rata & $\mathbf{9 . 0 6}$ & $\mathbf{6 . 2 2}$ & $\mathbf{3 1 . 4 \%}$ \\
\hline
\end{tabular}




\section{KESIMPULAN}

Hybrid Tsukamoto FIS dan algortima genetika dapat digunakan untuk melakukan optimasi batasan fungsi keanggotaan yang paling optimal untuk prediksi curah hujan di Daerah Batu, Jawa Timur. Setelah dilakukan pemodelan dan pengujian, didapatkan batasan fungsi keanggotaan yang optimal untuk memprediksi curah hujan menggunakan data historis dari empat lokasi pos hujan yaitu Junggo, Pujon, Tinjomulyo, dan Ngujung. Nilai error RMSE pada daerah Junggo sebesar 6.485, pada daerah Pujon sebesar 6.932, pada daerah Tinjomulyo sebesar 5.969, pada daerah Ngujung sebesar 5.498. Nilai RMSE tersebut $31.4 \%$ lebih bagus jika dibandingkan dengan penelitian sebelumnya yang menggunakan Tsukamoto FIS (Wahyuni \& Ahda, 2018).

\section{UCAPAN TERIMAKASIH}

Penelitian ini secara finansial didanai oleh Kementerian Riset, Teknologi, dan Pendidikan Tinggi (Kemenristekdikti) melalui program hibah Penelitian Dosen Pemula (PDP) dan Badan Meteorologi, Klimatologi, dan Geofisika Karangploso, Malang.

\section{DAFTAR PUSTAKA}

ARMANDA, R. S., \& MAHMUDY, W. F. (2016). Penerapan Algoritma Genetika Untuk Penentuan Batasan Fungsi Kenggotaan Fuzzy Tsukamoto Pada Kasus Peramalan Permintaan Barang. Teknologi Informasi Dan Ilmu Komputer(JTIIK), 3(3), 169-173.

BORCHERT, R. (1983). Phenology and control of flowering in tropical trees. Biotropica, 15(2), 81-89. https://doi.org/10.2307/2387949

BPS. (2015). Statistik Daerah Kota Batu 2015. Batu: BADAN PUSAT STATISTIK KOTA BATU.

GREFENSTETTE, J. (1986). Optimization of Control Parameters for Genetic Algorithms. IEEE Transactions on Systems, Man, and Cybernetics, 16(1), 122-128. https://doi.org/10.1109/TSMC.1986.289288

HANNAWATI, A., THIANG, \& ELEAZAR. (2002). Pencarian Rute Optimum Menggunakan Algoritma Genetika. Jurnal Teknik Elektro, 2(2), 78-83. Retrieved from http://puslit2.petra.ac.id/ejournal/index.php/elk /article/view/15857

HERMAN, N. S., YUSUF, I., \& MARIYAM, S. (2009). Genetic Algorithms and Designing Membership Function In Fuzzy Logic Controllers. World Congress on Nature \& Biologically Inspired Computing (NaBIC 2009), 1753-1758.

HERRERA, F., LOZANO, M., \& VERDEGAY, J. L. (1998). Tackling Real-Coded Genetic Algorithms: Operators and Tools for
Behavioural Analysis. Artificial Intelligence Review, 12, 265-319.

INDAHWATI, R., HERDRARTO, B., \& IZZATI, M. (2013). Perbedaan Kualitas Lahan Apel Sistem Pertanian Intensif dengan Sistem Pertanian Ramah Lingkungan ( Studi Kasus Di Kelompok Tani Makmur Abadi Desa Tulungrejo Kecamatan Bumiaji Kota Batu ) Abstrak. BIOMA, 15(2), 90-97.

JAFARIAN, J. (2010). An Experiment to Study Wandering Salesman Applicability on Solving the Travelling Salesman Problem based on Genetic Algorithm. International Conference on Educational and Information Technology (ICEIT 2010) An, (Iceit), 1-7.

KURNIANINGTYAS, D., MAHMUDY, W. F., \& WIDODO, A. W. (2017). Optimasi Derajat Keanggotaan Fuzzy Tsukamoto Menggunakan Algoritma Genetika Untuk Diagnosis Penyakit Sapi Potong. Jurnal Teknologi Informasi Dan Ilmu Komputer, 4(1), 8. https://doi.org/10.25126/jtiik.201741294

MAHMUDY, W. F., MARIAN, R. M., \& LUONG, L. H. S. (2012). Flexible Manufacturing System Using Real Coded Genetic Algorithms - Part I: Modeling. World Academy of Science, Engineering and Technology, 69, 773-779.

MAHMUDY, W. F., MARIAN, R. M., \& LUONG, L. H. S. (2013). Modeling and Optimization of Part Type Selection and Loading Problem in Flexible Manufacturing System Using Real Coded Genetic Algorithms. International Journal of Electrical, Computer, Energetic, Electronic and Communication Engineering, 7(4), 251-260.

MICHALEWICZ, Z. (1992). Algorithms + Data Structures = Evolution Programs. New York: Springer-Verlag.

MUHLENBEIN, H., \& SCHLIERKAMPVOOSEN, D. (1993). Predictive Models for the Breeder Genetic Algorithm. Evolutionary Computation, 1(1), 25-49.

TUTIN, C. E. G., \& FERNANDEZ, M. (1993). Relationships between minimum temperature and fruit production in some tropical forest trees in Gabon. Journal of Tropical Ecology, 9(2), 241-248. https://doi.org/10.1017/S0266467400007239

WAHYUNI, I., \& AHDA, F. A. (2018). Pemodelan Fuzzy Inference System Tsukamoto Untuk Prediksi Curah Hujan Studi Kasus Kota Batu. Jurnal Ilmiah Teknologi Dan Informasi ASIA (JITIKA), 12(2), 1-12.

WAHYUNI, I., \& MAHMUDY, W. F. (2017). Rainfall Prediction in Tengger-Indonesia Using Hybrid Tsukamoto FIS and Genetic Algorithm. Journal of ICT Research and 
Applications, $\quad 11(1), \quad 38-54$. https://doi.org/10.5614/itbj.ict.res.appl.2017.1 1.1.3

WAHYUNI, I., MAHMUDY, W. F., \& IRYANI, A. (2016). Rainfall Prediction in Tengger Region Indonesia Using Tsukamoto Fuzzy Inference System. 1st International Conference on Information Technology, Information Systems and Electrical Engineering, ICITISEE 2016, 16, 130-135. https://doi.org/10.1109/ICITISEE.2016.78030 61

WU, J., LONG, J., \& LIU, M. (2015). Evolving RBF neural networks for rainfall prediction using hybrid particle swarm optimization and genetic algorithm. Neurocomputing, 148, 136142.

https://doi.org/10.1016/j.neucom.2012.10.043 
Halaman ini sengaja dikosongkan 